\title{
AN ALTERNATIVE APPROACH TO THE ACTUAL BRAZILIAN MAIZE CROP ZONING
}

\author{
JÉSSICA DE SOUSA PAIXÃO ${ }^{1}$, CAMILO DE LELIS TEIXEIRA DE ANDRADE ${ }^{2}$, AXEL GARCIA \\ Y GARCIA ${ }^{3}$, TALES ANTÔNIO AMARAL ${ }^{4}$, ANTONIO JOSÉ STEIDLE NETO ${ }^{1}$ AND FÁBIO \\ RICARDO MARIN 5
}

\author{
1UFSJ, SeteLagoas, MG, Brasil, jessicaufsj@hotmail.com,antonio@ufsj.edu.br \\ ${ }^{2}$ Embrapa Milho e Sorgo, Sete Lagoas, MG, Brasil, camilo.andrade@embrapa.br \\ ${ }^{3}$ University of Minnesota, Minnesota, MN, USA, axel@umn.edu \\ ${ }^{4}$ UFPel, Pelotas, RS, Brasil, tales_aamaral@yahoo.com.br \\ ${ }^{5}$ USP, Piracicaba, SP, Brasil, fabio.r.marin@gmail.com
}

$\overline{\text { Revista Brasileira de Milho e Sorgo, v.13, n.3, p. 347-363, 2014 }}$

\begin{abstract}
Maize cropping under rainfed conditions are highly affected by the annual and intra-seasonal climate variability, especially dry spells, that affect yield. One of the simplest strategies with low cost to mitigate this problem is the determination of a sowing window. The study aimed to: a) use the maize yield simulated with a process-based model to establish sowing windows and, b) compare our results with the current Agricultural Crop Zoning of Climate Risk (ZRC) methodology employed by the Brazilian Ministry of Agriculture, Livestock and Supply (MAPA). The CSM-CERESMaize model was used to simulate scenarios of weekly sowing dates, under rainfed conditions, for selected counties of Minas Gerais State, Brazil. For each sowing date it was determined the yield break by comparing the average yield of the current sowing date with the highest average yield obtained from all sowing dates. The use of a process-based model to simulate crop yield allows for the integration of several factors not considered in the ZRC-MAPA approach. The proposed methodology has advantages over the ZRC-MAPA approach in that it includes the possibility of determining the expected average yield and its amplitude.
\end{abstract}

Key words: Zea mays L., climate risk; sowing window; modeling; DSSAT.

\section{UMA METODOLOGIA ALTERNATIVA PARA O ZONEAMENTO DE RISCO CLIMÁTICO DA CULTURA DO MILHO}

RESUMO - O cultivo de milho em regime de sequeiro é afetado pelas variabilidades climáticas anual e interanual, especialmente os veranicos, que reduzem a produtividade. Uma das estratégias mais simples e de baixo custo para mitigar esse problema é a determinação de uma janela de semeadura. O estudo objetivou: a) usar a produtividade de milho simulada com um modelo baseado em processos para estabelecer períodos de semeadura; e b) comparar os resultados obtidos com a atual metodologia do Zoneamento Agrícola de Risco Climático (ZRC) empregada pelo Ministério da Agricultura, Pecuária e Abastecimento (Mapa). Utilizou-se o modelo CSM-Ceres-Maize para simular cenários de épocas de semeadura semanais, sob condições de sequeiro, para municípios selecionados do estado de Minas Gerais. Para cada época de semeadura, determinou-se a quebra de rendimento, comparando o rendimento médio da época de semeadura atual com o maior rendimento médio obtido a partir de todas as datas de semeadura. O uso de um modelo baseado em processos para simular o rendimento das culturas permite a integração de muitos fatores não considerados na atual metodologia do ZRC-Mapa. A abordagem proposta tem vantagens sobre a metodologia do ZRC-Mapa, entre as quais a possibilidade de determinar o rendimento médio esperado e a sua amplitude.

Palavras-chave: Zea mays L., risco climático; janela de semeadura; modelagem; DSSAT. 
Grown in almost every continent, maize economic importance is characterized by the various forms of its use, from grazing to biofuels. Worldwide, Brazil is the third largest maize grower, with the state of Minas Gerais ranking third in production within the country (Agrianual, 2013). The average maize yield in Brazil is low with high variation within a region. In Minas Gerais, the average maize yield ranges from $6299 \mathrm{~kg} \mathrm{ha}^{-1}$ in the Triângulo Mineiro region to $1898 \mathrm{~kg} \mathrm{ha}^{-1}$ in the north region (IBGE, 2010). Possible causes of this low yield are related to the low level of technology employed by farmers, including sowing at inadequate time, water stress due to dry spells, and the use of cultivars with low adaptation to the region (Cruz et al., 2009; Forsthofer, 2004).

Minas Gerais agriculture is mainly rainfed. The rainfall in the state, ranging from $650 \mathrm{~mm}$ in the north region to $2100 \mathrm{~mm}$ in the south/southwest regions, is related to topography and geography (Santana, 2004; Guimarães et al., 2010). It is expected, therefore, that the main factor affecting maize yield in the state is water. Among all climatic factors, rainfall, temperature and solar radiation, are the most important as they directly affect the production of dry matter and grain (Sans \& Guimarães, 2006; Brachtvogel et al., 2009). Water availability and temperature are the most important factors to be considered to characterize the best growing seasons within a region (Wagner et al., 2013).

One strategy to minimize the risk of yield losses due to climatic conditions is sowing at the right time. The success of such approach is tightly related to the planning capability of the farmer as it is highly dependent on several factors associated to weather conditions (Sans \& Guimarães,
2006). The Brazilian Ministry of Agriculture, Livestock and Supply (MAPA) provides farmers with an Agricultural Crop Zoning of Climate Risk (ZRC) tool, which is also used by policy makers and risk management agencies. The ZRC-MAPA is prepared annually with the objective of minimizing the risks associated to weather and to allow producers to identify the best sowing window for various crops with varied cropping season and growing on different soil types (Brasil, 2013).

The ZRC-MAPA approach is based only on a soil-water balance approach. Process-based simulation models that simulate growth, development, and yield of crops based on weather, soil, cultivar-specific coefficients, and management practices, are better tools to assist in the determination of sowing windows. These dynamic crop models describe daily changes in the inputs used to simulate the main crop physiological processes (Dallacort et al., 2006). Dynamic crop simulation models are useful tools when the effects on crops depend on complex interactions with soil, weather and with other factors related to the management of agro-ecosystems (Jones et al., 2006). The CERES (Crop Environment Resource Synthesis) consists of group of models developed by the Grassland Soil and Water Research Laboratory (Jones \& Kiniry, 1986). Among the CERES models, CERES-Maize was developed for the maize crop and allows simulations of the growth and development of maize, water balance, $\mathrm{N}$ levels and also enables economic evaluations based on four input variables: soil, climate, crop management and genotypes (Soler, 2000). The cropping season of maize in the CERES-Maize is divided into various phases (germination, emergence, end of juvenile phase, floral induction, silking, beginning of 
grain filling, and harvest maturity), while development is influenced by the thermal sum or thermal time, expressed in degree-days (DD), which is calculated based on the minimum and maximum daily temperatures. The thermal time required to progress from one stage of development to another is a user input and can be defined as: P1 - Thermal time from seedling emergence to the end of the juvenile phase (expressed in DD above a base temperature of $8{ }^{\circ} \mathrm{C}$ ), during which the plant is not responsive to changes in photoperiod; P2 - Extent to which development (expressed in days) is delayed for each hour increase in photoperiod above the longest photoperiod at which development proceeds at a maximum rate (which is considered to be 12.5 hours); P5 - Thermal time from silking to physiological maturity (expressed in DD above a base temperature of $8{ }^{\circ} \mathrm{C}$ ); G2 - Maximum possible number of kernels per plant; G3 - Kernel filling rate during the linear grain filling stage and under optimum conditions ( $\mathrm{mg} \mathrm{day}{ }^{-1}$ ); PHINT - Phylochron interval, the interval in DD between successive leaf tip appearances (Ritchie et al., 1998; Jones et al., 2003). The CSM-CERES-Maize is part of the Decision Support System for Agrotechnology Transfer, DSSAT (Jones et al., 2003; Hoogenboom et al., 2013), a software that includes models for 28 different crops. The cropping system simulation model (CSM) included in DSSAT v4.5 simulates growth and development of maize at a daily time step, from planting to maturity. Several studies have demonstrated the applicability of DSSAT as a tool to help making management decisions. For example, a study conducted by Singh \& Srinivas (2007) in India aimed at determining best planting dates for irrigated and rainfed maize in a succession system with chickpeas. Soler et al. (2007) assessed the effect of different sowing dates for maize cultivars of different cycles growing on irrigated and rainfed fields for conditions in Manduri and Piracicaba counties, state of São Paulo, Brazil.

The objectives of this study were to use a simulation approach to determine best sowing windows for maize production and to compare those results with the current methodology employed by the ZRC-MAPA.

\section{Material and Methods}

The CSM-CERES-Maize model of DSSAT, version 4.5.1.013 (Hoogenboom et al., 2013) was used to simulate maize yield under rainfed conditions. The simulations were set weekly, from August 01 to July 24 for conditions in 49 of 853 counties of the State of Minas Gerais, Brazil (Figure 1). The counties were selected based on the availability of climate series data. Daily data were obtained from the National Institute of Meteorology (INMET) database for the period 1961 to 2010, totaling 49 years. Weatherman, a DSSAT tool to facilitate the manipulation of weather data, was used to analyze the consistency of the data, to fill up short periods ( $<7$ days) of gaps on air temperature and rainfall in the series and to estimate solar radiation from sunlight records.

The genetic coefficients of the single-cross hybrid BRS1030 were previously determined from observed data obtained from maize field trials conducted under optimum conditions of growth and development (Santana et al., 2010). The adjusted coefficients were 263.8 for $\mathrm{P} 1 ; 0.5$ for $\mathrm{P} 2 ; 1034$ for P5; 648 for G2; 5.14 for G3; 44.22 for PHINT. Because of the lack of specific soil information in the areas of interest (selected counties), the same 
approach used by the current ZRC-MAPA was used (Sans et al., 2001). The ZRC-MAPA criteria consists of a maize crop with a root system 0.50 $\mathrm{m}$ deep and three generic soil types with low (20 $\mathrm{mm})$, medium $(40 \mathrm{~mm})$ and high $(60 \mathrm{~mm})$ water retention capacity. The values of the lower and upper limits of available water of each layer of existing DSSAT's soil profiles data were adjusted to become similar, in terms of water retention, to the three soil types used in the ZRC-MAPA (Table 1).
The management conditions used in the simulations was obtained from the Embrapa Maize and Sorghum online recommendations for maize production (Cruz, 2009). The model was set for $0.90 \mathrm{~m}$ row spacing and a plant population of 68,000 plants ha $^{-1}$. Fertilization consisted of 500 $\mathrm{kg} \mathrm{ha}^{-1}$ of 8-28-16+ $\mathrm{Zn}$ applied at sowing and 200 $\mathrm{kg} \mathrm{ha}^{-1}$ of nitrogen as urea $+70 \mathrm{~kg} \mathrm{ha}^{-1}$ of $\mathrm{K}_{2} \mathrm{O}$ in, as potassium chloride, side-dressed at 40 days after sowing (DAS).

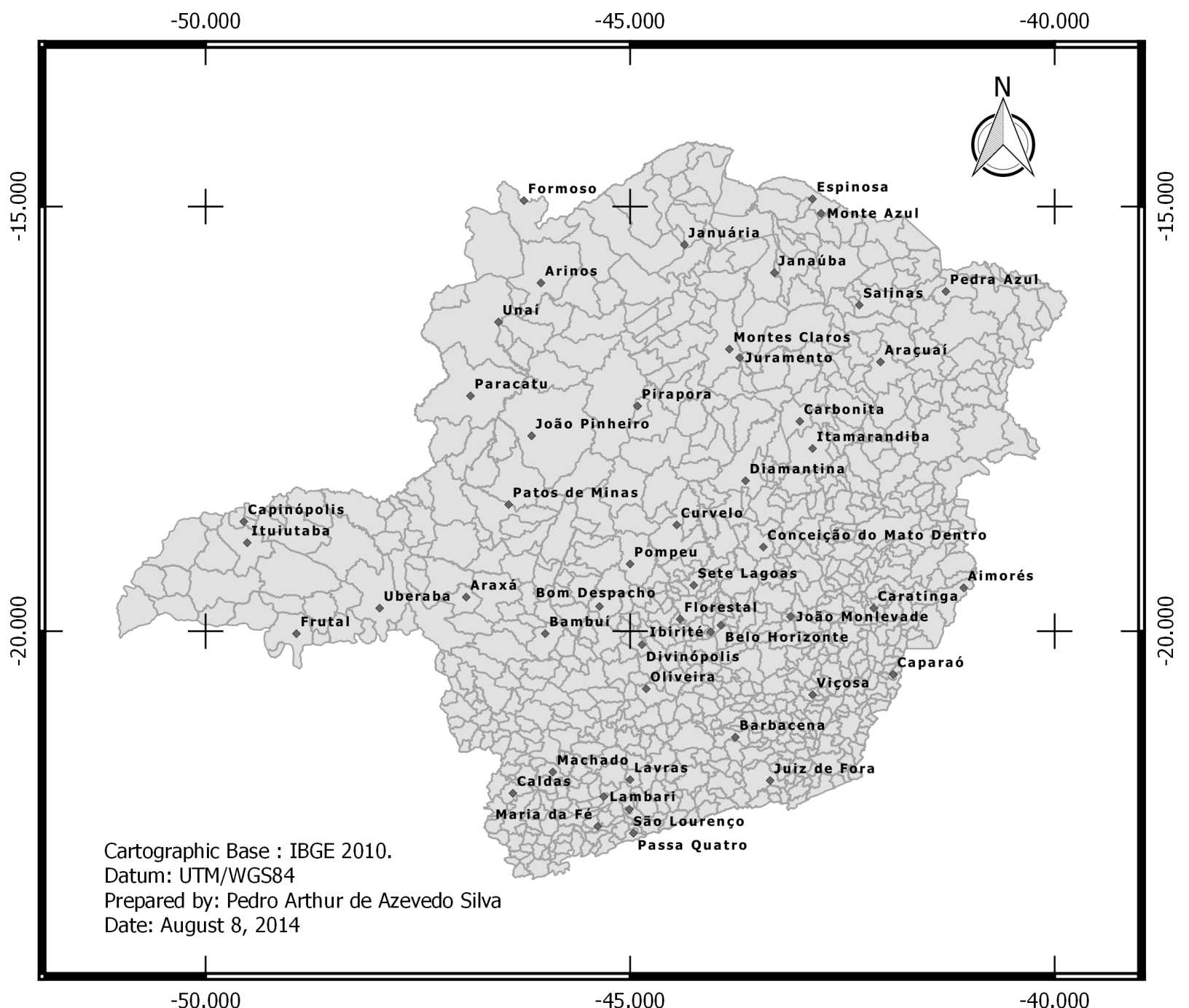

FIGURE 1. Location of weather stations of the state of Minas Gerais, Brazil, used in the study. 
TABLE 1. Attributes of the three generic soil profiles.

Soil type one

\begin{tabular}{|c|c|c|c|c|c|c|c|c|c|c|}
\hline $\begin{array}{l}\text { Layer } \\
\text { base } \\
\text { depth } \\
(\mathrm{m})\end{array}$ & $\begin{array}{l}\text { Lower } \\
\text { limit } \\
\left(\mathrm{m}^{3} \mathrm{~m}^{-3}\right)\end{array}$ & $\begin{array}{l}\text { Upper } \\
\text { limit } \\
\left(\mathrm{m}^{3} \mathrm{~m}^{-3}\right)\end{array}$ & $\begin{array}{c}\text { Saturation } \\
\left(\mathrm{m}^{3} \mathrm{~m}^{-3}\right)\end{array}$ & $\begin{array}{l}\text { Root } \\
\text { growth } \\
\text { factor }\end{array}$ & $\begin{array}{c}\text { Saturated } \\
\text { hydraulic } \\
\text { conductivity } \\
\left(\mathrm{m} \mathrm{h}^{-1}\right)\end{array}$ & $\begin{array}{c}\text { Bulk } \\
\text { density } \\
\left(\mathrm{kg} \mathrm{m}^{-3}\right)\end{array}$ & $\begin{array}{l}\text { Organic } \\
\text { carbon } \\
(\%)\end{array}$ & $\begin{array}{l}\text { Clay } \\
(\%)\end{array}$ & $\begin{array}{l}\text { Silt } \\
(\%)\end{array}$ & $\begin{array}{l}\mathrm{pH} \text { in } \\
\text { Water }\end{array}$ \\
\hline 0.05 & 0.050 & 0.075 & 0.438 & 1.0 & 0.682 & 1460 & 0.35 & 10 & 1 & 5.5 \\
\hline 0.10 & 0.050 & 0.075 & 0.438 & 1.0 & 0.682 & 1460 & 0.35 & 10 & 1 & 5.5 \\
\hline 0.20 & 0.060 & 0.085 & 0.416 & 1.0 & 0.601 & 1540 & 0.21 & 9 & 1 & 5.5 \\
\hline 0.40 & 0.067 & 0.095 & 0.429 & 0.8 & 0.625 & 1480 & 0.15 & 11 & 1 & 5.5 \\
\hline 0.60 & 0.067 & 0.110 & 0.439 & 0.5 & 0.327 & 1470 & 0.13 & 13 & 3 & 5.5 \\
\hline 0.80 & 0.067 & 0.114 & 0.450 & 0.2 & 0.451 & 1430 & 0.16 & 15 & 1 & 5.5 \\
\hline 1.00 & 0.067 & 0.125 & 0.441 & 0.0 & 0.436 & 1460 & 0.12 & 16 & 0 & 5.5 \\
\hline 1.20 & 0.067 & 0.125 & 0.441 & 0.0 & 0.436 & 1460 & 0.12 & 16 & 0 & 5.5 \\
\hline 1.50 & 0.067 & 0.125 & 0.441 & 0.0 & 0.436 & 1460 & 0.12 & 16 & 0 & 5.5 \\
\hline \multicolumn{11}{|c|}{ Soil type two } \\
\hline 0.05 & 0.290 & 0.340 & 0.568 & 1.0 & 0.0523 & 1050 & 2.18 & 63 & 19 & 5.7 \\
\hline 0.10 & 0.280 & 0.340 & 0.577 & 1.0 & 0.0977 & 1020 & 2.10 & 63 & 22 & 5.8 \\
\hline 0.20 & 0.280 & 0.350 & 0.569 & 1.0 & 0.0881 & 1040 & 2.00 & 66 & 21 & 5.8 \\
\hline 0.40 & 0.280 & 0.340 & 0.580 & 0.8 & 0.0715 & 1010 & 1.79 & 70 & 17 & 5.5 \\
\hline 0.60 & 0.270 & 0.335 & 0.605 & 0.5 & 0.1474 & 904 & 1.65 & 72 & 13 & 5.1 \\
\hline 0.80 & 0.258 & 0.340 & 0.619 & 0.2 & 0.3011 & 910 & 1.53 & 72 & 14 & 5.0 \\
\hline 1.00 & 0.252 & 0.335 & 0.629 & 0.0 & 0.3725 & 880 & 1.43 & 72 & 14 & 5.0 \\
\hline 1.20 & 0.252 & 0.335 & 0.629 & 0.0 & 0.3725 & 880 & 1.43 & 72 & 14 & 5.0 \\
\hline 1.50 & 0.252 & 0.335 & 0.629 & 0.0 & 0.3725 & 880 & 1.43 & 72 & 14 & 5.0 \\
\hline \multicolumn{11}{|c|}{ Soil type three } \\
\hline 0.05 & 0.265 & 0.370 & 0.465 & 1.0 & 0.790 & 1310 & 2.03 & 26 & 36 & 6.4 \\
\hline 0.10 & 0.275 & 0.380 & 0.452 & 1.0 & 0.790 & 1350 & 2.03 & 26 & 36 & 6.4 \\
\hline 0.20 & 0.285 & 0.385 & 0.445 & 1.0 & 0.790 & 1370 & 2.03 & 27 & 37 & 6.4 \\
\hline 0.40 & 0.280 & 0.370 & 0.455 & 0.8 & 0.790 & 1340 & 2.03 & 27 & 37 & 6.4 \\
\hline 0.60 & 0.275 & 0.360 & 0.451 & 0.5 & 0.790 & 1350 & 0.44 & 27 & 37 & 6.7 \\
\hline 0.80 & 0.260 & 0.360 & 0.458 & 0.2 & 0.790 & 1330 & 0.44 & 29 & 36 & 6.7 \\
\hline 1.00 & 0.260 & 0.360 & 0.446 & 0.0 & 0.790 & 1360 & 0.29 & 25 & 32 & 7.3 \\
\hline 1.20 & 0.260 & 0.350 & 0.410 & 0.0 & 0.790 & 1470 & 0.15 & 20 & 28 & 7.9 \\
\hline 1.50 & 0.260 & 0.350 & 0.403 & 0.0 & 0.790 & 1490 & 0.15 & 18 & 31 & 7.9 \\
\hline
\end{tabular}


The seasonal analysis tool of DSSAT, which simulates yield for each sowing week and each year, was used. Additionally, the water and nutrient balance routine from the model was turned off to allow the simulation of maize potential yield, in which the crop is grown without any biotic or abiotic stresses. The model was set to perform weekly sowings, beginning on August 01 and extending for 52 weeks to July 24, generating 49 simulation scenarios at each county.

The highest average simulated yield was identified among all sowing dates and a yield break was calculated for each county according to (Amaral et al., 2009):

$$
\mathrm{Y}_{\mathrm{b}}=\left[1-\left(\mathrm{Y}_{\mathrm{w}} / \mathrm{Y}_{\max }\right)\right] \times 100
$$

where $\mathrm{Y}_{\mathrm{b}}$ is the yield break in percentage; $\mathrm{Y}_{\mathrm{w}}$ is the average yield of week " $\mathrm{w}$ " in $\mathrm{kg} \mathrm{ha}^{-1}$; and $\mathrm{Y}_{\max }$ is the maximum average yield among all weeks in $\mathrm{kg} \mathrm{ha}^{-1}$.

An analysis of the yield break curve was performed to determine the sowing windows for different levels of risk that the decision maker would be willing to take. We arbitrarily assumed a risk level of $10 \%$; i.e., the decision maker would tolerate a yield reduction of up to $10 \%$. In the example showed in Figure 2, the sowing windows would be from October 24 to December 19, October 17 to December 26 and from October 10 to December 26, for soil type 1, type 2 and type 3 , respectively.

The criteria used to determine whether a county was suitable or not for maize production was based on the relationship:

$$
\mathrm{Y}_{\mathrm{pr}}=\left[1-\left(\mathrm{Y}_{\mathrm{str}} / \mathrm{Y}_{\mathrm{pot}}\right)\right] \times 100
$$

where $\mathrm{Y}_{\mathrm{pr}}$ is the yield break relative to the potential yield in percentage; $\mathrm{Y}_{\text {str }}$ is the average rainfed yield, for the sowing window, in $\mathrm{kg} \mathrm{ha}^{-1}$ and $\mathrm{Y}_{\mathrm{pot}}$ is the average potential yield, for the same sowing window, in $\mathrm{kg} \mathrm{ha}^{-1}$. A county was considered suitable for maize production when Ypr was $60 \%$ or less. This procedure was performed for the three soil types in all counties.

The simulated yields from the 49 counties and for the three different soils were then interpolated by using a kriging procedure. The software gvSIG 1.11 (gvSIG, 2013) and Quantum GIS 1.9 (Quantum, 2013) were used to create the yield maps.

The yield break curve approach allowed determining the suitability for maize production and the establishment of a sowing window for each selected county as demonstrated for Uberaba, Minas Gerais, Brazil (Figure 2). Our results were compared with the suitability and sowing windows established by the ZRC-MAPA. Additionally, the average expected maize yield was determined for each soil type and county. Results for soil type 2, the most common in Brazil, were compared to the average estimated yield provided by the Brazilian Institute of Geography and Statistics (IBGE), for the period 2003 to 2011 .

\section{Results and Discussion}

Our results showed large maize yield variation as a consequence of the climatic diversity in the state of Minas Gerais, characterized by humid climate in the south to semi-arid climate in the north and northeastern regions (Figure 3 ).

The average yield of maize, for the sowing window, ranged from $750 \mathrm{~kg} \mathrm{ha}^{-1}$, in Espinosa, to $10,523 \mathrm{~kg} \mathrm{ha}^{-1}$, in Maria da Fé. Regardless of the soil-water retention capacity, the regions North, 
Jequitinhonha and Vale do Rio Doce, which are drier and warmer, presented the lowest yield, while the south region, which is wetter and has milder temperatures, showed the highest. Yields below $1,000 \mathrm{~kg} \mathrm{ha}^{-1}$ were considerably larger in the regions North, Jequitinhonha, Vale do Mucuri and Vale do Rio Doce, especially in soils with poor water holding capacity (soil type 1). For soils with medium or high water holding capacity (soils type 2 and type 3), the amplitude of the simulated yield was higher due to better crop response to nitrogen fertilization in years with more favorable climatic conditions (Figure 3 ). This yield variability observed in our results is the consequence of the interactions between crop, soil and climatic conditions, especially water. Crop productivity is the result of the interaction of various factors, especially those related to soil attributes. However, Bergamaschi et al. (2004), indicate that water is the main factor that affects maize yield worldwide.

There is a close relationship between the average simulated maize yield and elevation and latitude of the sites (Figure 4). The higher the latitude and altitude, the greater the simulated maize yields. This is because for conditions in Minas Gerais, rainfall and air temperature are related to both, elevation and latitude (Guimarães et al., 2010; Santana, 2004).

When comparing the average simulated yield of the sowing window, for soil type two, with the average maize yield estimated by IBGE, for the 2003 to 2011 period and for the same counties, considerable differences can be observed (Figure 5). These gaps indicate that the average maize

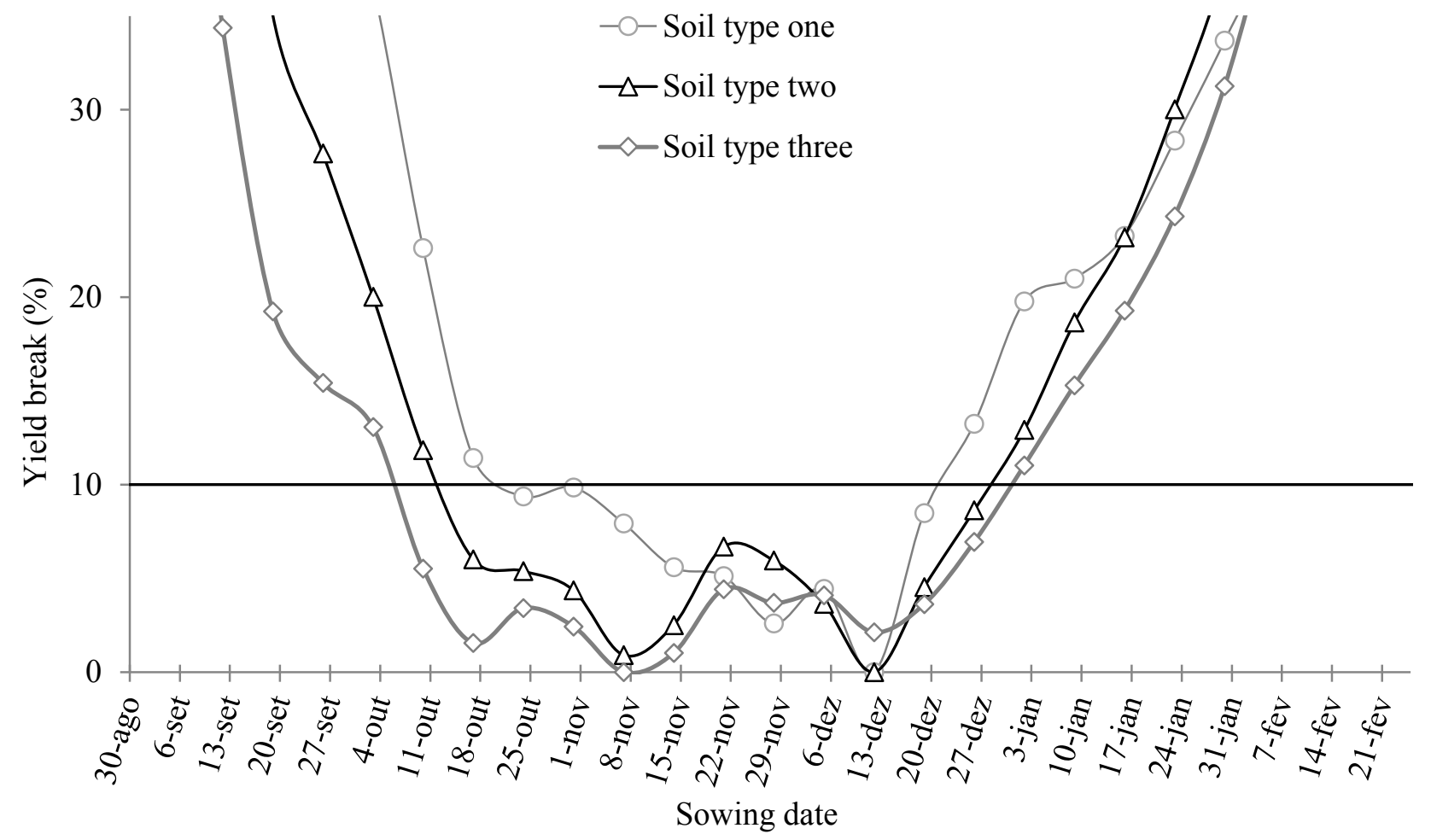

FIGURE 2. Maize yield break for different sowing dates in a rainfed production system for conditions in Uberaba, Minas Gerais, Brazil. 
yield is considerably lower than the potential yield in many counties. The largest yield gaps are in the southern counties, such as Maria da Fé, which has climatic conditions for high maize yields but rugged topography that is not suited for maize production.

On the other hand, in some counties, such as Uberaba, Unai and Frutal, the average simulated yields are lower than the average yield estimated by IBGE, indicating that in these counties the farmers are utilizing more technology, including cultivars better than the BRS1030 and, irrigation. Maize yield from Unai county is an unusual case because the IBGE data reflects the yield of farms located on the plateau, 300 meters above the location where the weather station is installed.
This difference in elevation has a considerable effect on maize yield mainly due to changes in the amount and distribution of rainfall and in temperature. According to a study conducted in the region by Landau et al. (2011) during the 2010 growing season, large increase in maize production were observed in the south/southwest and western (Campos das Vertentes) regions, eastern of Triângulo Mineiro, and west of the northwest region, which was in agreement with our results (Figure 3).

There is a large variation in the start and in the length of the sowing window (Table 2), as a consequence of the interactions between the crop and the weather conditions of the counties, captured by the simulation model. The shortest

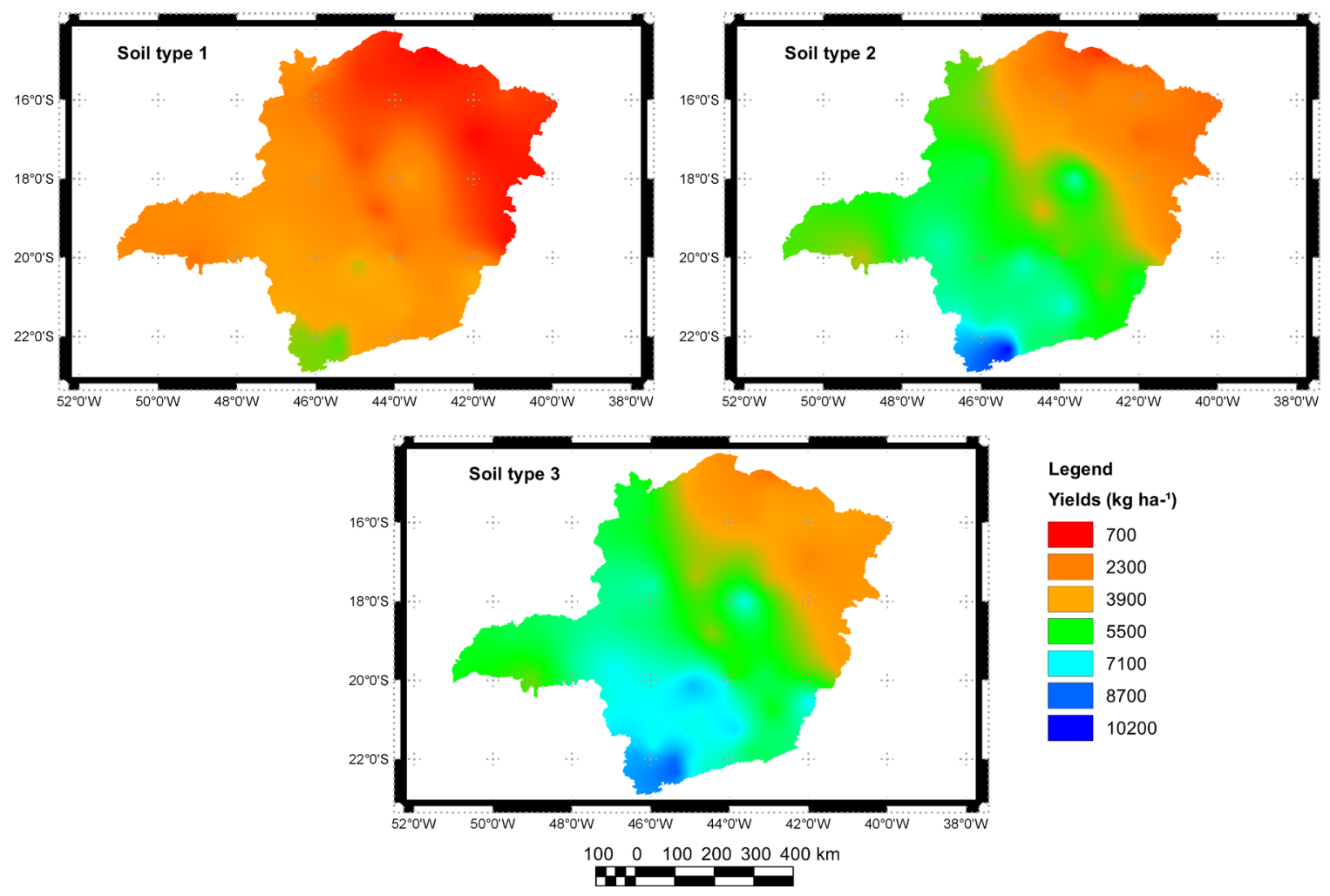

FIGURE 3. Distribution of the average simulated maize yield for the state of Minas Gerais, Brazil, considering soils with different water holding capacity. 

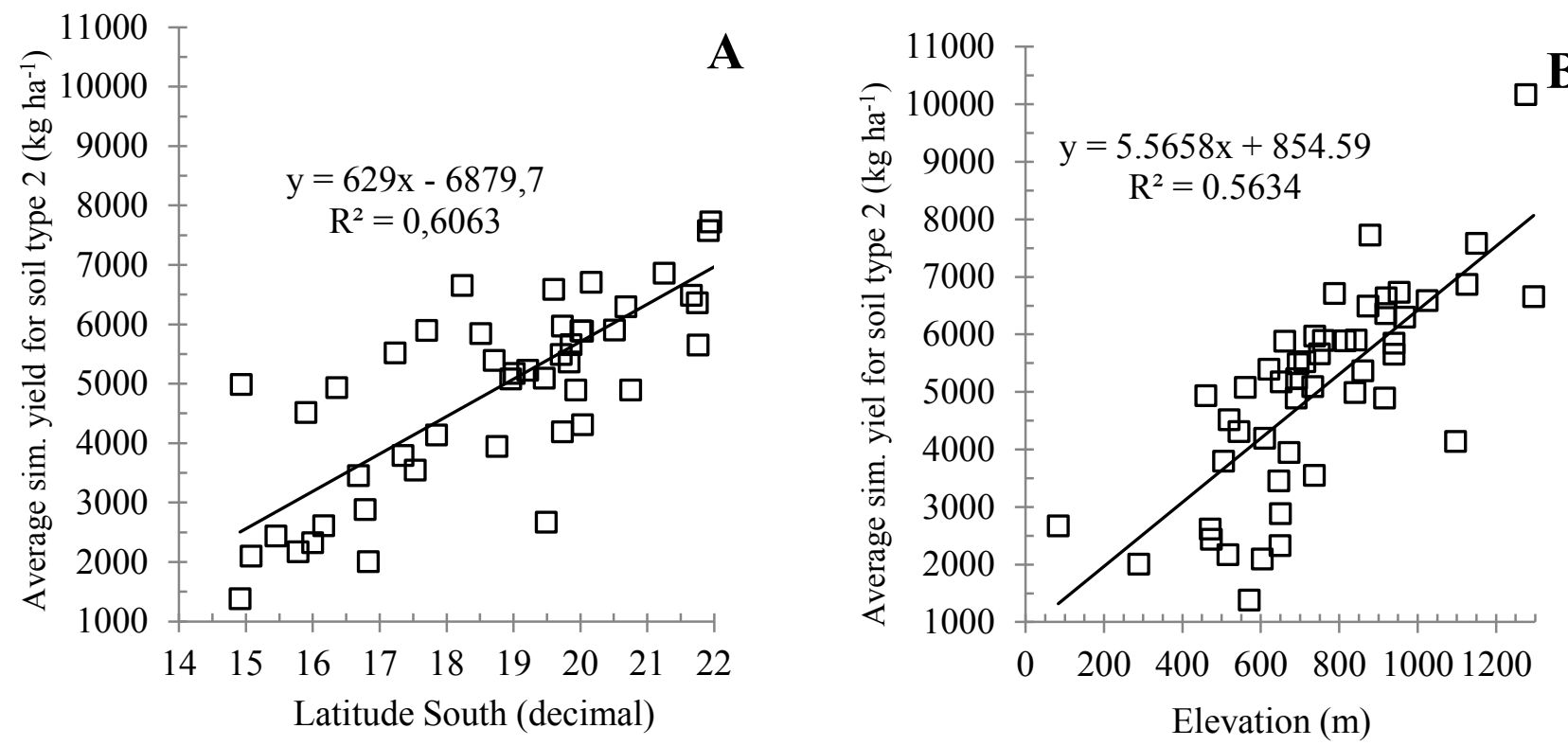

FIGURE 4. Maize yield in relation to latitude south (A) and to elevation (B), for soil type two.

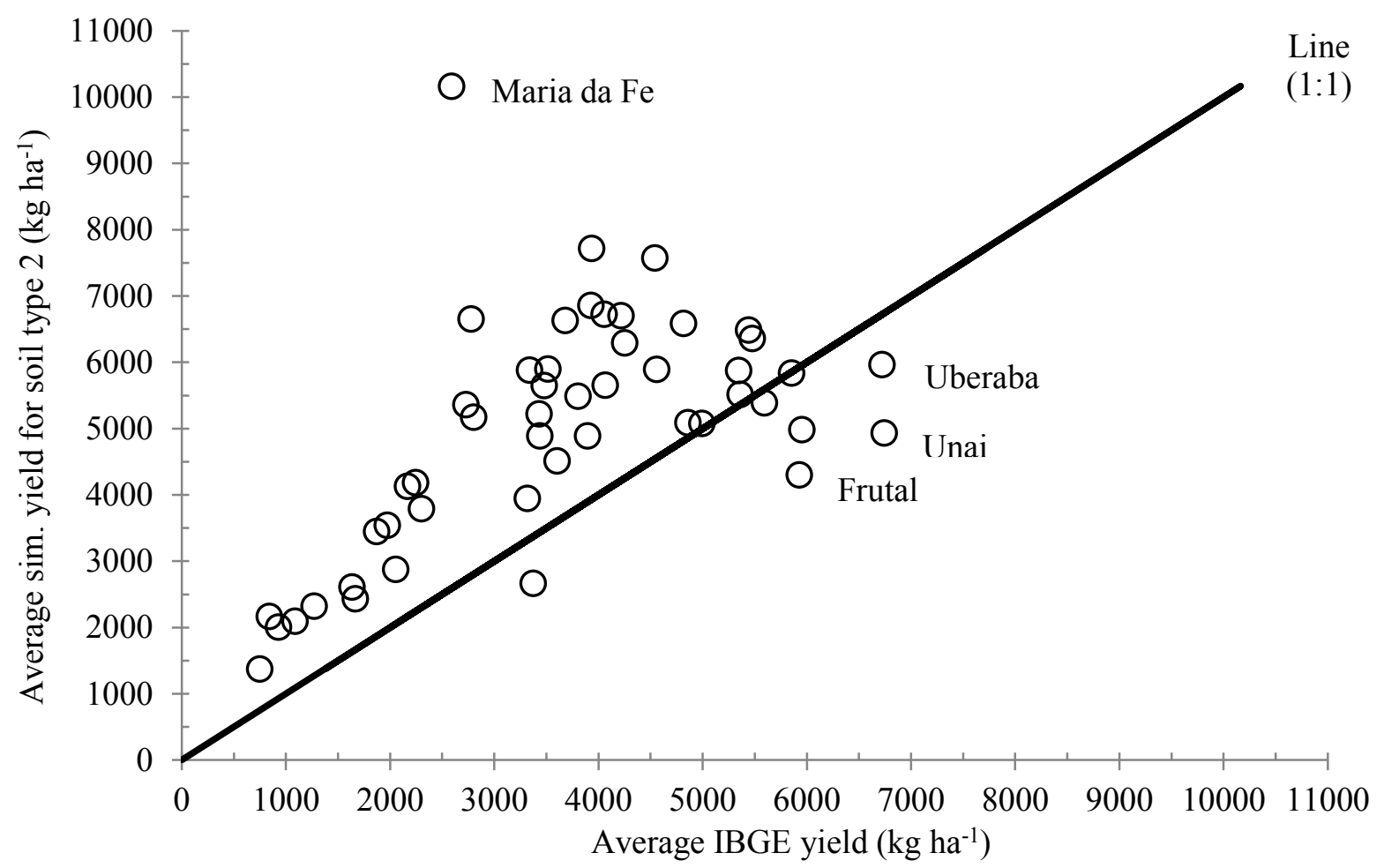

FIGURE 5. Average simulated yield for soil type 2 in relation to average yield estimated by IBGE, for the period of 2003-2011. 


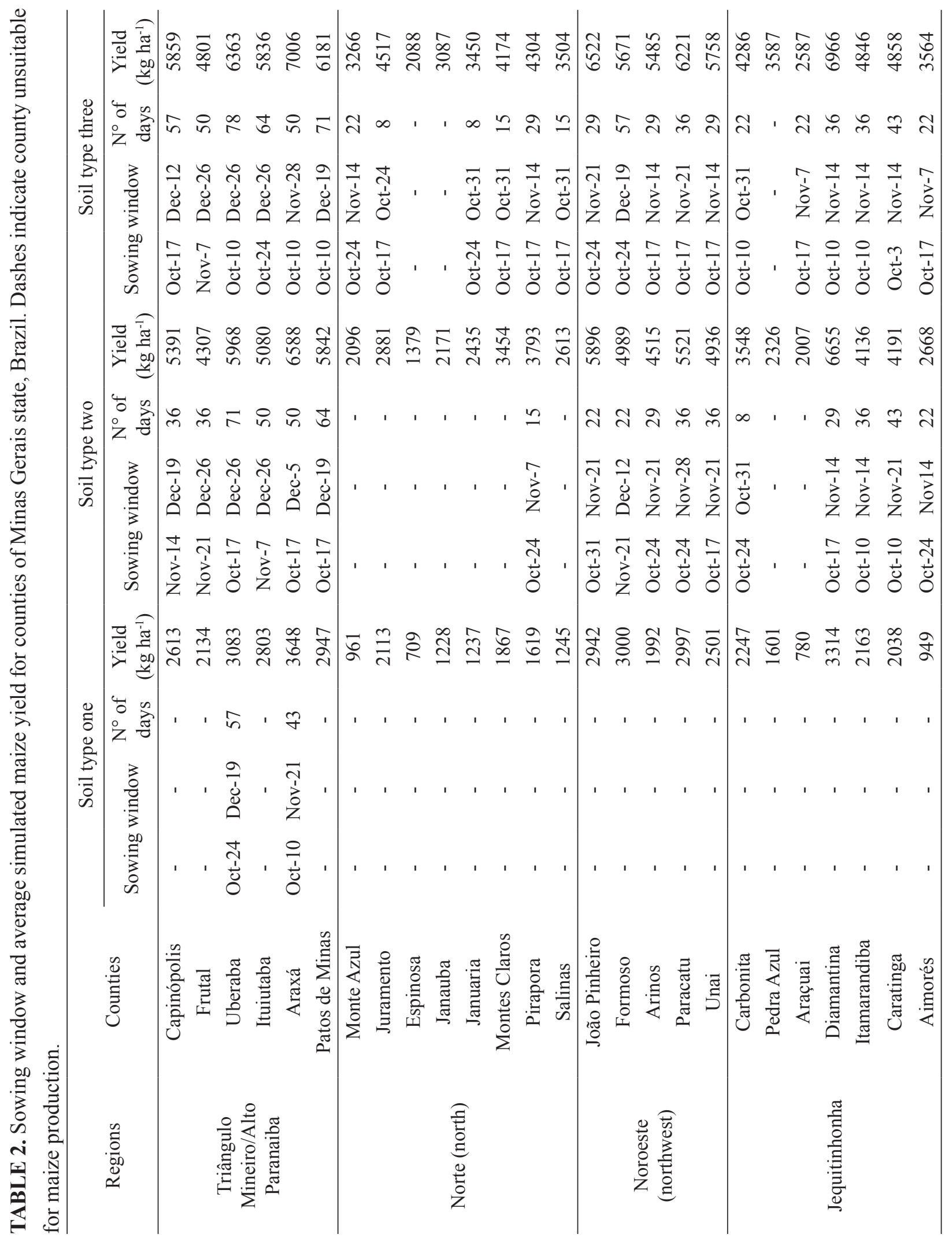




\begin{tabular}{|c|c|c|c|c|c|c|c|c|c|c|c|c|c|c|c|c|c|c|c|c|c|c|}
\hline$\frac{\nabla}{\sigma}$ & $\begin{array}{l}\infty \\
0 \\
0\end{array}$ & $\stackrel{尺}{\curvearrowright}$ & $\vec{n}$ & $\underset{\infty}{+}$ & $\frac{n}{\sigma}$ & $\underset{\infty}{\tilde{f}}$ & $\vec{\nabla}$ & $\underset{\infty}{\infty}$ & $\stackrel{\curvearrowright}{\curvearrowright}$ & $\stackrel{n}{n}$ & $\frac{m}{8}$ & 尔 & $\frac{n}{n}$ & $\stackrel{n}{\stackrel{\sim}{J}}$ & 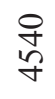 & $\begin{array}{l}8 \\
\approx 0 \\
0\end{array}$ & ڤై & సి & $\begin{array}{l}\text { ป్ } \\
\text { nิ }\end{array}$ & $\stackrel{2}{\frac{8}{6}}$ & 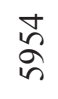 & さ્ \\
\hline in & in & సे & $\stackrel{\infty}{\curvearrowright}$ & t & t & in & $\stackrel{\infty}{\sim}$ & in & $\nabla$ & ల & $\hat{0}$ & in & ৯े & i & r & in & $\hat{n}$ & $\mathscr{\vartheta}$ & in & Әे & r & J \\
\hline 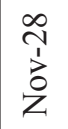 & $\begin{array}{l}\vec{\gamma} \\
\grave{z} \\
\dot{z}\end{array}$ & $\begin{array}{l}\frac{\Delta}{1} \\
\frac{1}{2} \\
z\end{array}$ & $\begin{array}{l}\stackrel{\sim}{\dot{d}} \\
\stackrel{\mathscr{D}}{0}\end{array}$ & $\begin{array}{l}\infty \\
\stackrel{1}{1} \\
\stackrel{1}{z} \\
z\end{array}$ & $\begin{array}{l}\frac{a}{\dot{\delta}} \\
\text { o. }\end{array}$ & $\begin{array}{l}n \\
\tilde{U} \\
\tilde{O}\end{array}$ & 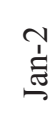 & $\begin{array}{l}n \\
\stackrel{\tilde{U}}{0}\end{array}$ & $\begin{array}{l}\frac{a}{\dot{\delta}} \\
\stackrel{\mathscr{0}}{0}\end{array}$ & 菅 & $\begin{array}{l}0 \\
\frac{1}{ \pm} \\
\stackrel{ \pm}{ \pm}\end{array}$ & 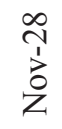 & $\begin{array}{l}\hat{1} \\
\text { za } \\
\text { ż }\end{array}$ & $\begin{array}{l} \pm \\
\frac{J}{\partial} \\
z\end{array}$ & $\begin{array}{l}\vec{\gamma} \\
\vec{z} \\
\vec{z}\end{array}$ & $\begin{array}{l}\stackrel{1}{1} \\
\text { Uू } \\
\stackrel{0}{0}\end{array}$ & $\begin{array}{l}n \\
\tilde{O} \\
\ddot{n}\end{array}$ & $\begin{array}{l}\vec{\gamma} \\
\vec{z} \\
\vec{z}\end{array}$ & $\begin{array}{l}\vec{\sim} \\
\vec{z} \\
\vec{z} \\
\dot{z}\end{array}$ & $\begin{array}{l}\hat{y} \\
z \\
z\end{array}$ & $\begin{array}{l}\frac{\partial}{1} \\
\frac{1}{2} \\
z\end{array}$ & $\begin{array}{l}n \\
\dot{\delta} \\
\stackrel{D}{0}\end{array}$ \\
\hline $\begin{array}{l}0 \\
\frac{1}{3} \\
0 \\
0\end{array}$ & $\frac{n}{0}$ & $\frac{\pi}{\frac{1}{U}}$ & 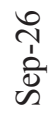 & $\begin{array}{l}\stackrel{2}{1} \\
\text { Lे } \\
\text { ڤn }\end{array}$ & $\frac{\pi}{\frac{1}{U}}$ & $\begin{array}{l}0 \\
\frac{1}{0} \\
0\end{array}$ & 䇋 & $\frac{0}{\frac{1}{U}}$ & $\begin{array}{l}0 \\
\frac{1}{U} \\
0 \\
0\end{array}$ & $\frac{n}{\stackrel{1}{U}}$ & $\frac{n}{\frac{1}{\delta}}$ & 䊝 & $\frac{0}{\frac{1}{U}}$ & $\begin{array}{l}0 \\
\frac{1}{U} \\
0\end{array}$ & $\frac{\pi}{\frac{1}{U}}$ & $\begin{array}{l}\vec{p} \\
\frac{1}{\delta}\end{array}$ & $\begin{array}{l}0 \\
\frac{1}{U} \\
0 \\
0\end{array}$ & $\begin{array}{l}0 \\
\frac{1}{U} \\
0\end{array}$ & 站 & $\begin{array}{l}0 \\
\frac{1}{U} \\
0\end{array}$ & $\frac{0}{1}$ & $\frac{n}{1}$ \\
\hline $\begin{array}{l}\tilde{D} \\
\infty \\
\infty \\
i n\end{array}$ & そิ & $\frac{8}{6}$ & $\widehat{\widehat{ర}}$ & $\stackrel{8}{\circ}$ & @্ণ & 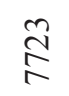 & $\frac{2}{n}$ & $\begin{array}{l}\widetilde{\delta} \\
\text { రె }\end{array}$ & $\overline{\frac{n}{6}}$ & $\begin{array}{l}\text { ô } \\
\text { in }\end{array}$ & $\begin{array}{l}\vec{n} \\
n \\
n\end{array}$ & $\underset{+}{\stackrel{+}{+}}$ & $\vec{a}$ & సิ & 文 & $\begin{array}{l}\hat{\sigma} \\
\text { in }\end{array}$ & $\begin{array}{l}\mathscr{n} \\
\stackrel{\infty}{+}\end{array}$ & $\stackrel{i}{n}$ & $\overline{\text { oे }}$ & $\begin{array}{l}\infty \\
\infty \\
\infty \\
n\end{array}$ & 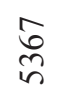 & $\begin{array}{l}\mathbb{0} \\
\infty \\
0 \\
0\end{array}$ \\
\hline in & $\mathscr{f}$ & r & $\hat{n}$ & $\nabla$ & $\vec{b}$ & in & in & $\vec{b}$ & $\nabla$ & $\hat{n}$ & ¿ & in & તี & $\approx$ & r & $\mathscr{q}$ & in & in & $\mathscr{\gamma}$ & in & $\approx$ & t \\
\hline 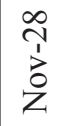 & $\begin{array}{l}\vec{T} \\
\vec{z} \\
\vec{z}\end{array}$ & $\begin{array}{l}\vec{\sim} \\
\vec{z} \\
z\end{array}$ & $\begin{array}{l}n \\
\dot{J} \\
0\end{array}$ & 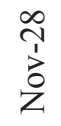 & $\begin{array}{l}\stackrel{a}{\dot{\delta}} \\
\text { ڤ. }\end{array}$ & $\begin{array}{l}n \\
\tilde{\delta} \\
\tilde{0}\end{array}$ & $\begin{array}{l}\text { İ } \\
\text { ̊̊ }\end{array}$ & $\frac{\sim}{\mathfrak{d}}$ & $\frac{a}{\dot{d}}$ & $\begin{array}{l}\stackrel{\infty}{N} \\
\text { İ } \\
\text { z }\end{array}$ & 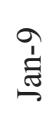 & $\begin{array}{l}\infty \\
\stackrel{1}{1} \\
\stackrel{1}{0} \\
z\end{array}$ & $\begin{array}{l} \pm \\
\frac{\Delta}{2} \\
z\end{array}$ & $\begin{array}{l}\frac{J}{1} \\
\text { 字 } \\
z\end{array}$ & $\begin{array}{l}\vec{\sim} \\
\vec{z} \\
\vec{z}\end{array}$ & 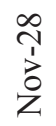 & $\begin{array}{l}n \\
\tilde{D} \\
\tilde{D}\end{array}$ & $\begin{array}{l}\infty \\
\stackrel{1}{1} \\
\stackrel{1}{0} \\
z\end{array}$ & $\begin{array}{l}\vec{\tau} \\
\stackrel{\vec{z}}{z} \\
\text { z }\end{array}$ & $\begin{array}{l}\infty \\
\stackrel{1}{1} \\
\stackrel{2}{z} \\
z\end{array}$ & $\begin{array}{l}\frac{\Delta}{1} \\
\dot{\partial} \\
z\end{array}$ & $\begin{array}{l}n \\
\dot{J} \\
\stackrel{D}{0}\end{array}$ \\
\hline $\begin{array}{l}0 \\
\frac{1}{0} \\
0\end{array}$ & $\begin{array}{l}0 \\
\frac{1}{0} \\
0\end{array}$ & $\frac{1}{\frac{1}{J}}$ & $\begin{array}{l}0 \\
\frac{1}{0} \\
0\end{array}$ & $\frac{a}{\frac{1}{2}}$ & $\frac{\pi}{\frac{1}{U}}$ & $\frac{1}{\frac{1}{0}}$ & $\begin{array}{l}r \\
z \\
z\end{array}$ & $\begin{array}{l}0 \\
\frac{1}{U} \\
0\end{array}$ & $\begin{array}{l}0 \\
\frac{1}{U} \\
0\end{array}$ & $\frac{n}{\tilde{J}}$ & $\frac{n}{\tilde{L}}$ & $\begin{array}{l}0 \\
\frac{1}{U} \\
0\end{array}$ & 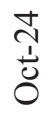 & $\frac{\stackrel{J}{N}}{\stackrel{I}{U}}$ & $\frac{1}{\frac{1}{U}}$ & $\frac{1}{\frac{1}{U}}$ & $\frac{1}{0}$ & $\begin{array}{l}0 \\
\frac{1}{U} \\
0\end{array}$ & $\begin{array}{l}0 \\
\frac{1}{0} \\
0\end{array}$ & $\begin{array}{l}\frac{0}{1} \\
\frac{1}{0}\end{array}$ & 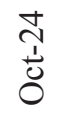 & $\frac{m}{\tilde{J}}$ \\
\hline $\begin{array}{l}0 \\
\stackrel{0}{n} \\
m\end{array}$ & $\underset{n}{n}$ & $\begin{array}{c}\mathscr{O} \\
\stackrel{N}{\sim}\end{array}$ & శ్రి & $\underset{\substack{\infty \\
+\infty}}{\stackrel{0}{2}}$ & ñ & & 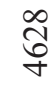 & ț & $\underset{\infty}{\infty}$ & તิ & 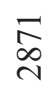 & $\underset{\infty}{\stackrel{\infty}{\Delta}}$ & $\begin{array}{l}\text { ळे } \\
\stackrel{\text { సे }}{ }\end{array}$ & 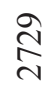 & $\stackrel{n}{n}$ & $\begin{array}{c}\text { ô } \\
\text { ᄋ్ }\end{array}$ & $\stackrel{\grave{N}}{\grave{N}}$ & $\stackrel{8}{\stackrel{8}{+}}$ & $\stackrel{\stackrel{\sim}{\sim}}{\underset{\sim}{\sim}}$ & $\frac{v}{n}$ & $\underset{i}{\mathbb{Z}}$ & $\underset{\infty}{\stackrel{\infty}{m}}$ \\
\hline i & $\approx$ & ה & ন & 1 & t & in & $\mathscr{\vartheta}$ & 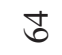 & $\stackrel{\infty}{\sim}$ & $n$ & $\nabla$ & ' & ' & ' & ' & ' & ' & ' & ' & $\because$ & ' & $\stackrel{\infty}{\sim}$ \\
\hline $\begin{array}{l}n \\
\tilde{\delta} \\
\tilde{D}\end{array}$ & $\begin{array}{l}\vec{n} \\
\stackrel{5}{0}\end{array}$ & 菅 & 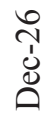 & ' & $\begin{array}{l}\frac{a}{\dot{\delta}} \\
\text { o. }\end{array}$ & $\begin{array}{l}\infty \\
\text { N } \\
\text { oे } \\
\text { z }\end{array}$ & 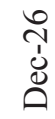 & $\begin{array}{l}\frac{a}{\dot{\delta}} \\
0 \tilde{0}\end{array}$ & $\frac{a}{\dot{d}}$ & $\begin{array}{l}n \\
\dot{\delta} \\
\stackrel{D}{0}\end{array}$ & $\begin{array}{l}\stackrel{\sim}{\dot{d}} \\
\stackrel{\Delta}{0}\end{array}$ & 1 & 1 & ' & ' & ' & ' & ' & ' & $\begin{array}{l}\vec{n} \\
\dot{1} \\
0\end{array}$ & ' & 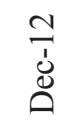 \\
\hline $\begin{array}{l}\vec{n} \\
\frac{1}{0} \\
0\end{array}$ & 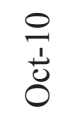 & $\frac{1}{\frac{1}{0}}$ & $\frac{a}{\frac{1}{2}}$ & ' & $\frac{1}{\frac{1}{0}}$ & $\frac{0}{\frac{1}{2}}$ & \begin{tabular}{l} 
\pm \\
\multirow{2}{*}{} \\
Z
\end{tabular} & $\frac{1}{\frac{1}{U}}$ & 先 & $\frac{0}{1}$ & $\frac{n}{\tilde{L}}$ & ' & ' & 1 & ' & ' & ' & ' & ' & $\frac{1}{\frac{1}{0}}$ & ' & $\begin{array}{l}\stackrel{0}{1} \\
\stackrel{\Delta}{\Delta} \\
\tilde{n}\end{array}$ \\
\hline 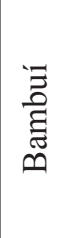 & $\stackrel{\frac{\pi}{0}}{\stackrel{0}{0}}$ & 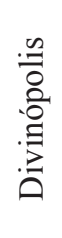 & 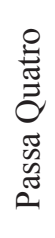 & 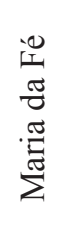 & $\begin{array}{l}\frac{0}{Z} \\
\frac{\pi}{0} \\
0 \\
\Sigma\end{array}$ & 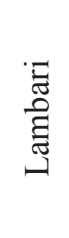 & $\frac{\tilde{J}}{\frac{\pi}{\pi}}$ & $\begin{array}{l}\tilde{J} \\
\stackrel{\Xi}{\Xi}\end{array}$ & 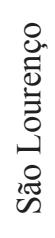 & 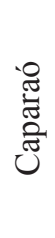 & $\begin{array}{l}\tilde{0} \\
0 \\
0 \\
0 \\
0 \\
\Xi \\
\Xi\end{array}$ & 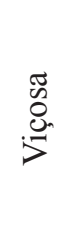 & 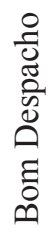 & 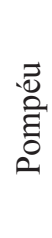 & 总 & 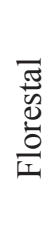 & 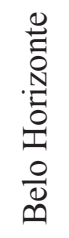 & 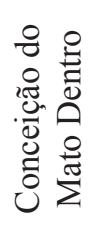 & 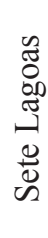 & : & $\begin{array}{l}\frac{0}{0} \\
\stackrel{0}{0} \\
\frac{0}{J} \\
\sum_{0}^{0} \\
0 \\
0 \\
0 \\
0\end{array}$ & 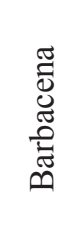 \\
\hline & 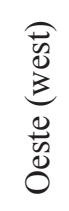 & & & & & 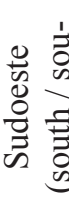 & $\begin{array}{l}\widehat{\vec{b}} \\
\hat{z}\end{array}$ & & & & 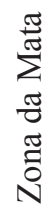 & & & U & & & & 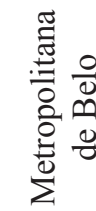 & 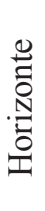 & & & 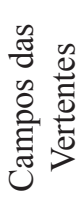 \\
\hline
\end{tabular}


sowing windows, of eight days, were simulated for counties in the North and Jequitinhonha regions, which are the driest and have the highest temperatures. The longest windows were simulated for the south/southwest and Zona da Mata regions (Table 2). The soil water retention capacity had an important role in defining the start and length of the sowing window, especially in cities with low rainfall.

Shorter sowing windows were also associated with lower yields (Figure 3 and Table 2). It is possible that the sowing date used by farmers is not the most appropriate for each site, contributing to lower than expected yields indicated by the estimates made by IBGE (Figure 5). Sowing out of the appropriate period is the major cause of low maize yield in Brazil (Forsthofer, 2004).

The methodology used to define the suitability of a certain county for dryland maize production proved consistent (Table 2). Most of the counties that were considered unsuitable for maize production are located in the North and Jequitinhonha regions, which receive lower amounts of precipitation and, in some cases, are associated with high temperatures. Obviously, the smaller the water holding capacity of the soils, the greater the number of counties considered unsuitable for rainfed maize production.

When comparing the sowing window and the suitability of the county for maize production (Tables 2 and 3), it can be observed that the proposed methodology is more restrictive than the ZRC-MAPA approach. According to the proposed methodology, and regardless of soil type, the counties of Espinoza, Janauba and Pedra Azul are not suitable for rainfed maize production, while when using the ZRC-MAPA approach those same counties are only suitable for maize production if the soil is of type three. If the soil has low water holding capacity (soil type 1), 34 counties are considered non suitable for rainfed maize production, against nine counties considered non suitable by the ZRC-MAPA approach. For soils with average water holding capacity (soil type 2), nine counties are considered non suitable by the proposed method while all counties are considered suitable by the ZRC-MAPA approach. For the ZRC-MAPA approach (Table 3), the beginning of the sowing window in all counties and for the three soil types, is October 01, while by the proposed methodology (Table 2), the starting of the sowing window ranged from September 19, in Passa Quatro and Maria da Fé, to November 21, in Formoso. Additionally, by the proposed methodology, the duration of the sowing window varied from eight days in Juramento, Januaria and Carbonita to 107 days, in Juiz de Fora.

For the ZRC-MAPA approach the expected duration of the sowing window is $31,20,20$ and 92 days, respectively for Juramento, Januaria, Carbonita and Juiz de Fora. In general, in drier regions the proposed methodology was more restrictive than the ZRC-MAPA approach, establishing shorter sowing windows.

The discrepancy in the results obtained with the proposed methodology and the ZRCMAPA is due to the use of different approaches to determine the sowing window and the suitability of the different counties for maize production. The ZRC-MAPA is based solely on crop water requirements satisfaction, determined through a simple soil water balance (Sans et al., 2001). The proposed methodology is based on a yield break curve, obtained from a process-based 
model, which takes into consideration the crop response to several factors, including air temperature, radiation and water requirements. The CSMCERES-Maize model, used in the present study, simulates growth, development and yield of crops deterministically resulting in accurate predictions of the variables of interest; i.e., without any probability distribution or random element associated. One of the advantages of the proposed methodology is the ability to estimate the expected average yield for each county, which is not provided by the ZRC-MAPA approach. On the other hand, the ZRC-MAPA approach only considers a land area as suitable for maize production if the crop water requirement satisfaction index is greater than 0.6 , something that was not considered in the proposed methodology.

The shortest sowing windows and lowest yields were found to be in the North, Jequitinhonha and Vale do Rio Doce regions by both methodologies. These results properly reflect the low levels of economic and social development of those regions, which economies are primarily based in agriculture. The human development index for the North and Jequitinhonha regions are in the range of 0.568 to 0.707 as compared to 0.744 to 0.841 from of Triângulo and south regions (Santos \& Pales, 2012).

Based on this study, it is evident that the current ZRC-MAPA can be improved through the use of process-based simulation models. However, calibration of model's coefficient for new cultivars and characterization of soil and climate for other Brazilian counties is required. Through the use of the proposed methodology one could improve policies for technology transfer and for granting credit for maize production.

\section{Conclusões}

The use of process-based simulation model allowed the establishment of sowing windows as well as the determination of the expected average maize yield for various counties in the state of Minas Gerais, Brazil.

Our results indicate that there is a potential to increase rainfed maize yield for conditions in the state of Minas Gerais.

The proposed methodology turned out to be more restrictive than the approach currently used by the ZRC-MAPA.

The study highlights the needs for better monitoring of environmental conditions in the state of Minas Gerais, a necessary step to enable the widespread application of the proposed methodology.

\section{Acknowledgements}

To the National Institute of Meteorology (INMET) for providing the historical weather data used in this study. To Embrapa and Monsanto for their support through the project: Evaluation mechanisms of adaptation and genome association applied to the development of genetic resources of cereals drought tolerant.

\section{Referências}

AGRIANUAL. Anuário da agricultura brasileira São Paulo: Instituto FNP, 2013. 480 p.

AMARAL, T.A.;ANDRADE C. L. T.; OLIVEIRA, A. C.; SILVA, D. F.; SANTANA, C. B.; MOURA, B. F.; CASTRO, L. A. Metodologia para o estabelecimento do período de semeadura 
TABLE 3. Sowing window and number of days of the sowing window for different counties of Minas Gerais state, Brazil, as established by the ZRC-MAPA.

\begin{tabular}{|c|c|c|c|c|c|c|c|c|c|c|}
\hline \multirow[b]{2}{*}{ Regions } & \multirow[b]{2}{*}{ Counties } & \multicolumn{3}{|c|}{ Soil type one } & \multicolumn{3}{|c|}{ Soil type two } & \multicolumn{3}{|c|}{ Soil type three } \\
\hline & & \multicolumn{2}{|c|}{ Sowing window } & \multirow{2}{*}{$\begin{array}{c}\begin{array}{c}\mathrm{N}^{\circ} \text { of } \\
\text { days }\end{array} \\
61\end{array}$} & \multicolumn{2}{|c|}{ Sowing window } & \multirow{2}{*}{$\begin{array}{c}\mathrm{N}^{\circ} \text { of } \\
\text { days }\end{array}$} & \multicolumn{2}{|c|}{ Sowing window } & \multirow{2}{*}{$\begin{array}{r}\begin{array}{r}\mathrm{N}^{\circ} \\
\text { of } \\
\text { days }\end{array} \\
92\end{array}$} \\
\hline \multirow{6}{*}{$\begin{array}{c}\text { Triângulo } \\
\text { Mineiro/Alto } \\
\text { Paranaiba }\end{array}$} & Capinópolis & Oct-1 & Nov-30 & & Oct-1 & Dec-31 & & Oct-1 & Dec-31 & \\
\hline & Frutal & Oct-1 & Dec-31 & 92 & Oct-1 & Dec-31 & 92 & Oct-1 & Dec-31 & 92 \\
\hline & Uberaba & Oct-1 & Dec-31 & 92 & Oct-1 & Dec-31 & 92 & Oct-1 & Dec-31 & 92 \\
\hline & Ituiutaba & Oct-1 & Dec-31 & 92 & Oct-1 & Dec-31 & 92 & Oct-1 & Dec-31 & 92 \\
\hline & Araxá & Oct-1 & Dec-31 & 92 & Oct-1 & Dec-31 & 92 & Oct-1 & Dec-31 & 92 \\
\hline & Patos de Minas & Oct-1 & Nov-10 & 41 & Oct-1 & Dec-31 & 92 & Oct-1 & Dec-31 & 92 \\
\hline \multirow{8}{*}{ Norte (north) } & Monte Azul & - & - & - & Oct-1 & Oct-20 & 20 & Oct-1 & Oct-31 & 31 \\
\hline & Juramento & - & - & - & Oct-1 & Oct-31 & 31 & Oct-1 & Nov-10 & 41 \\
\hline & Espinosa & - & - & - & Oct-1 & Oct-20 & 20 & Oct-1 & Oct-20 & 20 \\
\hline & Janauba & - & - & - & Oct-1 & Oct-31 & 31 & Oct-1 & Nov-10 & 41 \\
\hline & Januaria & Oct-1 & Oct-20 & 20 & Oct-1 & Oct-31 & 31 & Oct-1 & Nov-10 & 41 \\
\hline & Montes Claros & Oct-1 & Oct-20 & 20 & Oct-1 & Oct-31 & 31 & Oct-1 & Nov-10 & 41 \\
\hline & Pirapora & - & - & - & Oct-1 & Oct-31 & 31 & Oct-1 & Nov-10 & 41 \\
\hline & Salinas & - & - & - & - & - & - & Oct-1 & Oct-31 & 31 \\
\hline \multirow{5}{*}{$\begin{array}{l}\text { Noroeste } \\
\text { (northwest) }\end{array}$} & João Pinheiro & Oct-11 & Oct-20 & 10 & Oct-1 & Dec-31 & 92 & Oct-1 & Dec-31 & 92 \\
\hline & Formoso & Oct-1 & Oct-20 & 20 & Oct-1 & Oct-31 & 31 & Oct-1 & Nov-20 & 51 \\
\hline & Arinos & Oct-1 & Oct-20 & 20 & Oct-1 & Oct-31 & 31 & Oct-1 & Dec-20 & 81 \\
\hline & Paracatu & Oct-1 & Nov-30 & 61 & Oct-1 & Dec-31 & 92 & Oct-1 & Dec-31 & 92 \\
\hline & Unai & Oct-1 & Nov-10 & 41 & Oct-1 & Nov-30 & 61 & Oct-1 & Dec-10 & 71 \\
\hline \multirow{7}{*}{ Jequitinhonha } & Carbonita & Oct-1 & Oct-20 & 20 & Oct-1 & Nov-10 & 41 & Oct-1 & Nov-20 & 51 \\
\hline & Pedra Azul & - & - & - & Oct-1 & Oct-20 & 20 & Oct-1 & Oct-31 & 31 \\
\hline & Araçuai & - & - & - & Oct-1 & Oct-20 & 20 & Oct-1 & Oct-31 & 31 \\
\hline & Diamantina & Oct-1 & Oct-31 & 31 & Oct-1 & Nov-20 & 51 & Oct-1 & Nov-30 & 61 \\
\hline & Itamarandiba & Oct-1 & Oct-20 & 20 & Oct-1 & Nov-10 & 41 & Oct-1 & Nov-20 & 51 \\
\hline & Caratinga & Oct-1 & Oct-20 & 20 & Oct-1 & Nov-10 & 41 & Oct-1 & Nov-20 & 51 \\
\hline & Aimorés & - & - & - & Oct-1 & Oct-31 & 31 & Oct-1 & Oct-31 & 31 \\
\hline
\end{tabular}




\begin{tabular}{|c|c|c|c|c|c|c|c|c|c|c|}
\hline \multirow{3}{*}{ Oeste (west) } & Bambuí & Oct-1 & Nov-30 & 61 & Oct-1 & Dec-31 & 92 & Oct-1 & Dec-31 & 92 \\
\hline & Oliveira & Oct-1 & Nov-30 & 61 & Oct-1 & Dec-31 & 92 & Oct-1 & Dec-31 & 92 \\
\hline & Divinópolis & Oct-1 & Nov-10 & 41 & Oct-1 & Dec-31 & 92 & Oct-1 & Dec-31 & 92 \\
\hline \multirow{7}{*}{$\begin{array}{c}\text { Sul / } \\
\text { Sudoeste } \\
\text { (south / sou- } \\
\text { thwest) }\end{array}$} & Passa Quatro & Oct-1 & Dec-31 & 92 & Oct-1 & Dec-31 & 92 & Oct-1 & Dec-31 & 92 \\
\hline & Maria da Fé & Oct-1 & Dec-31 & 92 & Oct-1 & Dec-31 & 92 & Oct-1 & Dec-31 & 92 \\
\hline & Machado & Oct-1 & Dec-20 & 81 & Oct-1 & Dec-31 & 92 & Oct-1 & Dec-31 & 92 \\
\hline & Lambari & Oct-1 & Dec-20 & 81 & Oct-1 & Dec-31 & 92 & Oct-1 & Dec-31 & 92 \\
\hline & Caldas & Oct-1 & Dec-31 & 92 & Oct-1 & Dec-31 & 92 & Oct-1 & Dec-31 & 92 \\
\hline & Lavras & Oct-1 & Dec-20 & 81 & Oct-1 & Dec-31 & 92 & Oct-1 & Dec-31 & 92 \\
\hline & São Lourenço & Oct-1 & Dec-20 & 81 & Oct-1 & Dec-31 & 92 & Oct-1 & Dec-31 & 92 \\
\hline \multirow{3}{*}{ Zona da Mata } & Caparao & Oct-1 & Oct-20 & 20 & Oct-1 & Nov-10 & 41 & Oct-1 & Nov-20 & 51 \\
\hline & Juiz de Fora & Oct-1 & Nov-20 & 51 & Oct-1 & Nov-30 & 61 & Oct-1 & Dec-31 & 92 \\
\hline & Viçosa & Oct-1 & Nov-10 & 41 & Oct-1 & Dec-31 & 92 & Oct-1 & Dec-31 & 92 \\
\hline \multirow{3}{*}{ Central } & Bom Despacho & Oct-1 & Oct-31 & 31 & Oct-1 & Nov-20 & 51 & Oct-1 & Dec-31 & 92 \\
\hline & Pompéu & Oct-1 & Oct-31 & 31 & Oct-1 & Nov-20 & 51 & Oct-1 & Dec-31 & 92 \\
\hline & Curvelo & Oct-1 & Oct-20 & 20 & Oct-1 & Nov-10 & 41 & Oct-1 & Nov-30 & 61 \\
\hline \multirow{6}{*}{$\begin{array}{c}\text { Metropolitana } \\
\text { de Belo } \\
\text { Horizonte }\end{array}$} & Florestal & Oct-1 & Nov-20 & 51 & Oct-1 & Dec-31 & 92 & Oct-1 & Dec-31 & 92 \\
\hline & Belo Horizonte & Oct-1 & Nov-20 & 51 & Oct-1 & Dec-31 & 92 & Oct-1 & Dec-31 & 92 \\
\hline & $\begin{array}{c}\text { Conc. do Mato } \\
\text { Dentro }\end{array}$ & Oct-1 & Nov-10 & 41 & Oct-1 & Nov-30 & 61 & Oct-1 & Dec-31 & 92 \\
\hline & Sete Lagoas & Oct-1 & Oct-31 & 31 & Oct-1 & Nov-20 & 51 & Oct-1 & Nov-30 & 61 \\
\hline & Ibirité & Oct-1 & Nov-20 & 51 & Oct-1 & Dec-31 & 92 & Oct-1 & Dec-31 & 92 \\
\hline & João Monlevade & Oct-1 & Oct-31 & 31 & Oct-1 & Nov-20 & 51 & Oct-1 & Nov-30 & 61 \\
\hline $\begin{array}{c}\text { Campos das } \\
\text { Vertentes }\end{array}$ & Barbacena & Oct-1 & Nov-20 & 51 & Oct-1 & Dec-31 & 92 & Oct-1 & Dec-31 & 92 \\
\hline
\end{tabular}


de milho. Sete Lagoas: Brasil. Embrapa Milho e Sorgo. 13 p. 2009. (Embrapa Milho e Sorgo. Documentos 88).

BERGAMASCHI, H.; DALMAGO, G. A.; BERGONCI, J. I.; BIANCHI, C. A. M.; MÜLLER, A. G.; COMIRAN, F.; HECKLER, B. M. M. Distribuição hídrica no período crítico do milho e produção de grãos. Pesquisa Agropecuária Brasileira, Brasília, DF, v. 39, p. 831-839, 2004.

BRACHTVOGELL, E. L., PEREIRA, F. R. S.; CRUZ, S. C. S.; BICUDO, S. J. Densidades populacionais de milho em arranjos espaciais convencional e equidistante entre plantas. Ciência Rural, Santa Maria, v. 39, n. 8, p. 2334-2339, 2009.

BRASIL. Ministério da Agricultura, Pecuária e Abastecimentos. Zoneamento Agrícola de Risco Climático. Disponivel em: $<\mathrm{http}: / /$ www.agricultura.gov.br/politica-agricola/ zoneamento-agricola > Acesso em: 21 mai. 2013.

CRUZ, J. C. (Ed.). Cultivo do milho. 5. ed. Sete Lagoas: Embrapa Milho e Sorgo, 2009. (Embrapa Milho e Sorgo. Sistemas de produção, 1).

CRUZ, J. C.; PEREIRA FILHO, I. A.; GARCIA, J. C.; GOMES, P. H. A.; FERNANDES, J. S. C; ALBERNAZ, W. M. Avaliação de sistemas de produção de milho na região de Sete Lagoas, MG. Sete Lagoas: Embrapa Milho e Sorgo, 2009. 6 p. (Embrapa Milho e Sorgo. Circular Técnica, 123).

DALLACORT, R.; FREITAS. P. S. L.; FARIA, R. T.; GONÇALVES, A. C. A.; RESENDE, R.; BERTONHA, A. Utilização do modelo Cropgrosoybean na determinação de melhores épocas de semeadura da cultura da soja, na região de Palotina, Estado do Paraná. Acta Scientiarum, Maringá. V. 28, n. 4, p. 583-589.Maringá, v. 28, n. 4, p. 583-589, Out./Dez., 2006.

FORSTHOFER, E. L. Rendimento de grãos e desempenho econômico do milho em cinco níveis de manejo e três épocas de semeadura. 2004. 96 f. Dissertação (Mestrado em Fitotecnia)

- Faculdade de Agronomia, Universidade Federal Rio Grande do Sul, Porto Alegre.

GUIMARÃES, D. P.; REIS, R. J. R.; LANDAU, E. C. Índices Pluviométricos em Minas Gerais. Sete Lagoas: Embrapa Milho e Sorgo, 2010. 88 p. (Embrapa Milho e Sorgo. Boletim de pesquisa e desenvolvimento, 30).

gvSIG 1.11. 2013. Available at: www.gvsig.org/web/. Acessed in: 7 june 2013.

HOOGENBOOM, G.; JONES, J. W.; WILKENS, P. W.; PORTE, C. H.; BOOTE, K. J.; HUNT, L. A.; SINGH, U.; LIZASO, J. L.; WHITE, J. W.; URYASEV, O.; ROYCE, F. S.; OGOSHI, R.; GIJSMAN, A. J.; TSUJI, G. Y. Decision Support System for Agrotechnology Transfer: version 4.5.1.013. Honolulu: University of Hawaii, 2013. 1 CD-ROM.

IBGE. Instituto Brasileiro de Geografia e Estatística. Levantamento sistemático da produção agrícola. 2010. Disponivel em: $<\mathrm{http}: / / \mathrm{www}$. ibge.gov.br>. Acesso em: 25 abr. 2013.

JONES, J. W.; HOOGENBOOM, G.; PORTER, C. H.; BOOTE, K. J.; BATCHELOR, W. D.; HUNT, L. A.; WILKENS, P. W.; SINGH, U.; GIJSMAN, A. J.; RITCHIE, J. T. DSSAT cropping system model. European Journal of Agronomy, Amsterdam, v. 18, p. 235-265, 2003.

JONES, J. W.; MAKOWSKI, D.; WALLACH, D. Introduction to section II. In: WALLACH, D.; 
MAKOWSKI, D.; JONES, J. W. Working with dynamic crop models: evaluation, analysis, parameterization and applications. Amsterdam: Elsevier, 2006. p. 251-256.

LANDAU, E. C.; GUIMARÃES, L. S.; PENNA, L. B. Variação da produção estadual de milho no Brasil entre 2000 e 2009. Sete Lagoas: Embrapa Milho e Sorgo, 2011. 42 p. Disponivel em: <http:/www.infoteca.cnptia. embrapa.br/bitstream/doc/920747/1/bol39. pdf $>$. Acesso em: 24 set. 2013.

Quantum GIS. 2013. Disponível em: www.qgis.org/. Acesso em: 7 jun. 2013.

SANS, L. M. A.; ASSAD, E. D.; GUIMARÃES, D. P.; AVELLAR, G. Zoneamento de riscos climáticos para a cultura de milho na Região Centro-Oeste do Brasil e para o estado de Minas Gerais. Revista Brasileira de Agrometeorologia, Santa Maria, v. 9, n. 3, p. 1-10, 2001. No Especial: Zoneamento Agrícola. SANS, L. M. A.; GUIMARÃES, D. P. Zoneamento Agrícola de Riscos Climáticos para a Cultura do Milho. Sete Lagoas: Embrapa Milho e Sorgo, 2006. 5 p (Embrapa Milho e Sorgo. Documentos, 82).

SANTANA, C. B.; ANDRADE, C. L. T.; AMARAL, T. A.; SILVA, D. F.; MOURA, B. F.; CASTRO, L.A. Parametrização do modelo Ceres-Maize para cultivares de milho. In: SEMINÁRIO DE INICIAÇÃO CIENTÍFICA PIBIC/BIC JÚNIOR, 1., 2010, Sete Lagoas. [Trabalhos apresentados]. Sete Lagoas: Embrapa Milho e Sorgo, 2010. 1 CD-ROM.

SANTANA, M. O. Análise espaço-temporal do regime de chuvas e seus efeitos no rendimento agrícola no estado de Minas Gerais. 2004. 155 f. (Doutorado) - Universidade Federal de Viçosa, MG.

SANTOS, G. R.; PALES, R. C. Desenvolvimento regional e desigualdades sociais entre as macrorregiões de planejamento de Minas Gerais. In: ENCONTRO ANUAL DA ANPOCS, 36, 2012, Montes Claros. 2012. Disponivelem: $<$ http://www.anpocs.org/portal/ index.php?option $=$ com_docman\&task $=\mathrm{doc}$ view\&gid $=7905 \&$ Itemid $=76>$. Acesso em: 21 jun. 2013.

SINGH, P.; SRINIVAS, K. Crop simulation models as decision-making tools for managing agricultural droughts. In: RAMAKRISHNA, Y. S.; RAO, G. G. S. N.; SASTRY, P. S. N.; RAO, V. U. M. (Ed.). Agricultural droughts: aspects of micrometeorology: a lecture notes of 4th SERC School. Hyderabad: CRIDA, 2007. SOLER, C. M. T.; SENTELHAS, P. C.; HOOGENBOOM, G. Application of the CSM-CERES - Maize model for planting date evaluation and yield forecasting for maize grown off-season in a subtropical environment.

European Journal of Agronomy, Amsterdam, v. 27, p. 165-177, 2007.

WAGNER, M. V.; SIDNEI O. JADOSKI, S. O.; MAGGI, M. F.; SAITO, L. R.; LIMA, A. S. Estimativa da produtividade do milho em função da disponibilidade hídrica em Guarapuava, PR, Brasil. Revista Brasileira de Engenharia Agrícola e Ambiental, Campina Grande, v. 17, n. 2, p. 170-179, 2013. 